\title{
Poezja świata, który stał się atrapą
}

\section{Pawee Dybel}

ORCID: 0000-0002-4757-999I

(Instytut Filozofii i Socjologii PAN, Warszawa)

RecenZja KsiążKi: Staniseaw Czerniak, Powrót zdarzeń, posŁowie Marek Pieczara, Instytut Wydawniczy Książka i Prasa, Warszawa 2019, ss. 156

Co się miało zdarzyć, już się wydarzyło.

Teraz wszystko się od-zdarza,

Zdarzenia wypadają z czasu i przestrzeni. Świadkowie powymierali.

(Stanisław Czerniak, Nieważkość)

Na mapie współczesnej poezji polskiej twórczość Stanisława Czerniaka zajmuje miejsce odrębne, nie dając się jednoznacznie przyporządkować dominującym w niej tendencjom i nurtom. Wynika to w dużej mierze z roli, jaką odgrywa w niej tzw. żywioł filozoficzności umiejętnie wplatany przez autora w poetycki dyskurs. W liryce tej aż roi się bowiem od filozoficznych toposów zaczerpniętych $\mathrm{z}$ wielowiekowej tradycji zachodniej metafizyki, podejmowane są w niej kluczowe pytania i problemy metafizyczne. Rozpatrywana pod tym kątem twórczość Czerniaka jest na naszym gruncie zjawiskiem oryginalnym. Żaden z jej wielkich poprzedników i patronów, którzy nie stronili od filozofii w swoich wierszach, jak Zbigniew Herbert czy Wisława Szymborska, nie posunął się w tej materii tak daleko. Osobliwość omawianej poezji polega na tym, że nawiązując do wszystkich tych wspomnianych filozoficznych toposów i pytań, ujawnia ona w poetyckim języku różne zawarte w nich założenia i implikacje, a często przewrotnie proponuje całkiem nowe odczytanie ich znaczenia. Innymi słowy, jest to poezja, w której filozoficzne myślenie stało się elementem „żywiołu poetyckości”, tworząc z nim nierozerwalny organiczny splot ${ }^{\mathrm{I}}$. 
Równocześnie od kilkunastu lat uwagę krytyków (Krzysztof Lisowski, Krzysztof Derdowski, Janusz Drzewucki, Andrzej Zieniewicz, Marek Pieczara, Paweł Dybel i inni) zwraca specyficzny styl tych wierszy, zdumiewający zwięzłością poetyckiej formuły, pomysłowością w ewokowaniu różnego rodzaju paradoksów językowych, połączony z dużym wyrafinowaniem intelektualnym oraz wyobrażeniową kreatywnością i inwencją. Istotnym wyznacznikiem tego stylu jest, nawiązujące do tradycji poezji lingwistycznej, upodobanie Czerniaka do rozmaitych gier językowych. Polegają one na przewrotnym, przez odpowiednie posłużenie się językowym kontekstem, udosłownianiu znaczeń poszczególnych słów, zwrotów lub przysłów, na ich parodiowaniu i zderzaniu z nieoczekiwanymi okolicznościami. Te zabiegi nie są tutaj jednak nigdy celem samym w sobie, ale stoi za nimi zawsze określone przesłanie ${ }^{2}$.

Dobry przykład stanowi wiersz Fraszka I, który został pomyślany jako rodzaj osobliwej poetyckiej „analizy” utartych potocznie powiedzeń i zwrotów:

\section{Jak się nie ma, co się lubi, to się lubi, co się ma. \\ Ale najpierw trzeba lubić mieć. \\ Może nawet lubić lubić. \\ (Są rodzaje ascezy, które sobą pogardzają). (Fraszka I)}

Wiarygodność przywołanego powyżej potocznego, znanego powiedzenia została obwarowana dwoma dodatkowymi warunkami, składającymi się na ,jeżeli..." (tutaj "Jak...”). Potwierdza się ono bowiem jedynie wówczas, gdy, po pierwsze, podmiot „lubi” posiadać jakąś rzecz (zadowolenie z tego, że coś się ma), oraz, po drugie, gdy lubi samo lubienie, a więc, że coś, obojętnie co, ma. Są przecież ludzie, którzy nie lubią tego, co mają, jeśli nie jest ono tym, co naprawdę pragną mieć.

Innego typu „analizę” proponuje Czerniak w odniesieniu do potocznego określenia „nie ma”. Wychodzi od konkluzji, że w naszej egzystencji nie tylko zawsze czegoś nam brakuje, ale w dodatku: „świat nie ma/ świata, bo mu się wymyka,/ jest jestestwu,/ dłoń dłoni,/ nie ma tego, co jest,/ jest nie ma” (Nie ma). „Nie ma” stanowi więc nieodłączny i niewymazywalny moment naszego sposobu bycia i bycia świata, w którym nic nie jest do końca w pełni tożsame ze sobą. Dlatego paradoksalnie to ono przede wszystkim ,jest”. Ten przewrotny „analityczny” styl poezji Czerniaka dobrze uchwycił w Postowiu do zbiorku Marek Pieczara, nazywając go poetą ,intelektualnej draki”, który: 
sytuuje swoją poetycką uwagę na granicy naszego świata, odwracając porządek rzeczywistości i niejako wychodząc poza jej ramy. Mówimy wtedy o poezji metafizycznej, która przekracza doświadczenie bytu i świata fizycznego, danego nam w obserwacji, rozrywa łańcuch przyczynowo-skutkowy i odwraca bieg czasu3 .

Można więc powiedzieć, że w liryce tej poetycka „lingwistyka” spotyka się z metafizyką. Docieranie do granic języka i w pewnym sensie jego przekraczanie jest zarazem docieraniem do punktu, w którym byt styka się z nicością.

W wielu wierszach zbioru Czerniak podejmuje, pojawiające się w jego poezji już wcześniej, kwestie relacji między ludzką , duszą” (psychiką, samowiedzą) a ciałem oraz stosunku człowieka do zwierząt i do ziemi. W tym pierwszym wypadku podkreślana jest paradoksalna obcość wobec siebie obu tych sfer (wiersz Casting), w drugim są obnażane różne uzurpacyjne formy ludzkiej dominacji wobec świata zwierząt. W ogóle świat zwierząt, który w tekstach Czerniaka reprezentują szczególnie bliskie człowiekowi psy i koty, fascynuje już od pierwszych tomików autora Iskry buntu swoją zagadkową odmiennością. Mimo iż udomowione, tworzą one własny świat, do którego człowiek nie ma dostępu (Smutek zwierząt). Człowiek z kolei jest według Czerniaka przede wszystkim istotą, która pasożytuje na języku. Poezja natomiast stanowi najwyższe wcielenie tego pasożytnictwa.

W Ars poetica VII zestawiane są po kolei różne koncepcje poezji. Taka, w której twierdzi się, że stanowi o niej prywatny język, co jednak okazuje się niemożliwe do zrealizowania, oraz taka, w której utrzymuje się, że jest ona grą nastrojów i wrażeń. Tyle że wówczas zatraca się gdzieś poetyckie ,ja”:

\author{
》W końcu język zaczyna \\ wskazywać na siebie, \\ zjada siebie, potem zjada swego żywiciela, \\ produkuje w zamian \\ niejasne poszlaki, \\ że w kolejnym wierszu \\ pojawi się dla nich obu \\ możliwość \\ zmartwychwstania. \\ Ars poetica VII
}

3 M. Pieczara, Poeta intelektualnej draki, posłowie w: S. Czerniak, Powrót zdarzeń, Warszawa 2019, s. 117. 
Dotychczasowa ewolucja koncepcji poetyckości nie kończy się zatem na Mallarmégo teorii poezji czystej, której język jest nastawiony na siebie, i będącej jej pochodną poezji lingwistycznej. Jej apogeum jest akt podwójnej autodestrukcji języka i poety, utożsamiony z najwyższym aktem samo-kanibalizmu. Dopiero po osiągnięciu tego stanu zero w słowach wiersza - rodzi się mglista nadzieja zmartwychwstania. Tyle że jego możliwość otworzy się dopiero w następnym, bardziej udanym wierszu.

W zbiorze pojawia się również problematyka historiozoficzna. Kluczowe znaczenie w tym kontekście ma tytułowy Powrót zdarzeń, w którym można znaleźć nawiązanie do głośnego twierdzenia Fryderyka Nietzschego o wiecznym powrocie tego samego: „Co będzie potem?/ Przedtem./ Zdarzenia powracają/ po kolistych orbitach;/ Nietzsche sądził,/ że to wieczny proces.// A czy Nietzsche już powrócił?/ Zapewne./ Pod postacią nadludzi, których opisywat,/ twierdzących, że ich wola mocy/ musi stać się prawem" (Powrót zdarzeñ). Wiersz ten to kolejny wymowny przykład podejmowania przez Czerniaka poetyckiej dyskusji ze znanymi filozoficznymi koncepcjami. W tym wypadku autor sarkastycznie zauważa, że w historii najnowszej głoszony przez Nietzschego „powrót” zapisał się pojawieniem się tych, którzy zaczęli uważać siebie za nadludzi ustanawiających jedynie prawdziwe, „wieczne" prawo $z$ własnej mocy. Tak oto towarzyszące człowiekowi od zarania jego kultury wyobrażenia na temat wieczności przeobrażają się często w historycznej i politycznej praktyce w swoje karykaturalne przeciwieństwo. Dlatego być może o wiele lepiej będzie dla niego, gdy je porzuci i „pójdą wreszcie wszyscy spać” (Powrót zdarzén).

W Powrocie zdarzeń uwagę zwraca również nasilenie się tonu ironicznej - niekiedy wręcz sarkastycznej - krytyki dzisiejszego świata, którego uproszczony, nakierowany na produkowanie taniej sensacji obraz jest kształtowany w coraz większym stopniu przez sieci internetowe, smartfony, gry komputerowe i inne media. Dlatego dominujące znaczenie zyskują w tym świecie narcystyczne formy identyfikacji oraz postępująca instrumentalizacja relacji międzyludzkich. To głęboko pesymistyczna poetycka diagnoza współczesności. Nakłania ona do refleksji nad tym, co stało się dzisiaj z człowiekiem i z otaczającą go rzeczywistością.

W wyniku nasilenia się wspomnianych procesów promowanych przede wszystkim przez popularne internetowe portale i strony - Facebook, Instagram, Twitter i inne media społecznościowe - człowiek wyobcowuje się coraz bardziej wobec rzeczywistości. Zaczyna gonić za tanią sensacją, obnaża publicznie różne intymne szczegóły swego życia prywatnego, staje się seksualnym ekshibicjonistą, przesadnie eksponuje własne ja (np. wiersze takie jak: Casting, Nieważkość, Wtedy, Wizualność). Czerniak demaskuje w swoich utworach stojące za tymi postawami schematy my- 
ślowe oraz stawia ich bohaterów w nietypowych sytuacjach, w których wszystkie wspomniane powyżej zjawiska i tendencje są doprowadzone do absurdu. W wierszu Wtedy chce zrobić sobie zdjęcie z niedźwiedziem jaskiniowym, a potem, „wrzucić je/ do Internetu.// Wtedy by się działo, po raz pierwszy coś by się zdarzyło/ w trzecim tysiącleciu" (Wtedy).

Sposób myślenia o sobie i świecie bohaterów tych wierszy ma charakter kalkulacyjny, nastawiony na sprawienie sobie jakiejś chwilowej przyjemności. Jest więc hochsztaplerski i powierzchowny. To wersja umysłu zamkniętego, ukształtowanego przez współczesne mechanizmy kultury konsumpcyjnej. U jego podstaw tkwi przekonanie, że wszystkie problemy i kwestie, nawet te czysto egzystencjalne, da się na tym świecie rozwiązać, choćby przez opłacenie odpowiednio w nich wyspecjalizowanej firmy. W wierszu Swojski poczqtek na przykład jakaś firma zgłosiła ofertę posprzątania wszystkiego po końcu świata. Inna sprawa, że w tym wypadku chodzi o sprzątanie po końcu świata poetyckiego, po którym wszystko mogłoby zacząć się od nowa. Albo się już nigdy nie zacząć... 